\title{
REVIEW
}

\section{Duality of glucocorticoid action in cancer: tumor-suppressor or oncogene?}

\author{
Isabel Mayayo-Peralta1, Wilbert Zwart1,2* and Stefan Prekovic1* \\ 1Division of Oncogenomics, Oncode Institute, the Netherlands Cancer Institute, Amsterdam, the Netherlands \\ 2Laboratory of Chemical Biology and Institute for Complex Molecular Systems, Department of Biomedical Engineering, Eindhoven University of \\ Technology, Eindhoven, the Netherlands
}

Correspondence should be addressed to W Zwart or S Prekovic: w.zwart@nki.nl or s.prekovic@nki.nl

*(W Zwart and S Prekovic contributed equally as senior authors)

\begin{abstract}
Glucocorticoid receptor (GR) is a key homeostatic regulator involved in governing immune response, neuro-integration, metabolism and lung function. In conjunction with its pivotal role in human biology, GR action is critically linked to the pathology of various disease types, including cancer. While pharmacological activation of GR has been used for the treatment of various liquid cancers, its role in solid cancers is less clearly defined and seems to be cancer-type dependent. This review focuses on the molecular aspects of GR biology, spanning the structural and functional basis of response to glucocorticoids, as well as how this transcription factor operates in cancer, including the implications in disease development, progression and drug resistance.
\end{abstract}

\author{
Key Words \\ - glucocorticoid receptor \\ - glucocorticoids \\ - nuclear receptor \\ - cancer \\ - transcriptional regulation
}

Endocrine-Related Cancer (2021) 28, R157-R171

\section{Introduction}

The fitness of a given organism is linked to its ability to adapt to various internal and external factors. Through the course of animal evolution, a group of transcription factors with a high affinity for sensing and reacting to various molecules of lipid nature has emerged (Markov $\&$ Laudet 2011). While the mode-of-activation of the common ancestor of these proteins, grouped within the nuclear receptor family, is still under debate, strong evidence exists that this protein was a molecular sensor capable of weakly binding to diverse hydrophobic molecules (e.g. steroids and fatty acids). It is proposed that duplications of a single ancestral receptor and divergent molecular evolution led to either loss of ligand binding (group of orphan receptors, reviewed elsewhere Baek \& Kim 2014, Mazaira et al. 2018) or specialization toward a certain ligand (Markov \& Laudet 2011). The evolutionary emergence of the steroid hormone receptor superfamily with the unique ability of sensing cholesterol-based metabolites came early in the animal lineage (Thornton 2001). These proteins are tightly, intrinsically bound to animal physiology and are causally linked to embryonic development, sex dimorphism, metabolism, salt balance regulation, neuro-integration, and immune system function (Guyton \& Hall 2006).

Among the members of this group is the glucocorticoid receptor (GR), specialized toward high-affinity sensing of glucocorticoids (GCs), hormones produced in the adrenal cortex. First evidence illustrating the importance of GCs in physiology came from adrenalectomized animal models. Although capable of surviving, these animals exhibit various metabolic alterations, homeostatic problems and are more likely to die due to mild diseases (e.g. airway infection) (Guyton \& Hall 2006). Studies with global and organ-specific GR-knockout models expanded and solidified our understanding of the biology of thisimportant ligand-controlled transcription factor and have been 
reviewed by others (Whirledge \& DeFranco 2018). Since GR is expressed almost ubiquitously, regulating various aspects of physiology, it is not surprising that alterations of its axis have been found to be causal or associated with numerous disorders, including the ones of the immune system, metabolism, and brain. In addition to that, GR activity or lack thereof has been linked to various aspects of cancer biology; however, its role in cancer seems to be complex and highly context-dependent, as GR has been proposed to be both a tumor suppressor as well as an oncogenic driver.

In this review, we aim to cover the molecular aspects of GR, spanning the structural and functional basis of response to GCs. We discuss how this transcription factor operates in cancer, including implications for disease development, progression and therapy resistance.

\section{The glucocorticoid receptor}

In the third quarter of the 20th century, GR was identified as a primary receptor responsible for sensing and reacting to GCs (Munck \& Brinck-Johnsen 1968). However, structural insights into the NR3C1 gene (chromosome 5 (5q31.3)) that encodes for GR were only obtained 17 years later when it became the first steroid hormone receptor to be successfully cloned (Hollenberg et al. 1985). The NR3C1 gene contains nine exons that encode for a modular protein with discrete specialized domains - aminoterminal domain (NTD), DNA-binding domain (DBD), hinge- and ligand-binding domain (LBD) (Giguère et al. 1986, Hollenberg \& Evans 1988, Hard et al. 1990, Bledsoe et al. 2002) (Fig. 1). The activity of GR is a direct output of allosteric changes induced by the ligand, different intradomain interactions, partner protein contacts, and the specific sequence of its response elements in the DNA (Gronemeyer \& Bourguet 2009, Meijsing et al. 2009, Watson et al. 2013).

The unstructured amino-terminal domain (NTD) of GR contains a constitutively active activation function 1 (AF1), which acts as an interaction hub for co-regulators, chromatin modifiers, and the basal transcription machinery (Vandevyver et al. 2014). In addition, this domain is a target of various post-translational modifications that can either repress or enhance receptor action (reviewed by Vandevyver et al. 2014). The ability of GR to bind to specific glucocorticoid response elements (GREs) on the DNA is afforded by two highly conserved zinc finger motifs, each containing four cysteine residues that tetrahedrally coordinate zinc ions (Freedman et al. 1988, Hard et al. 1990, Bledsoe et al. 2002, Meijsing et al. 2009). The first of the two zinc fingers contain the proximal box (P box), responsible for base-specific contact with the major groove of DNA. The other zinc finger engages in non-specific interactions with DNA via the minor groove and DNA helix backbone (Freedman

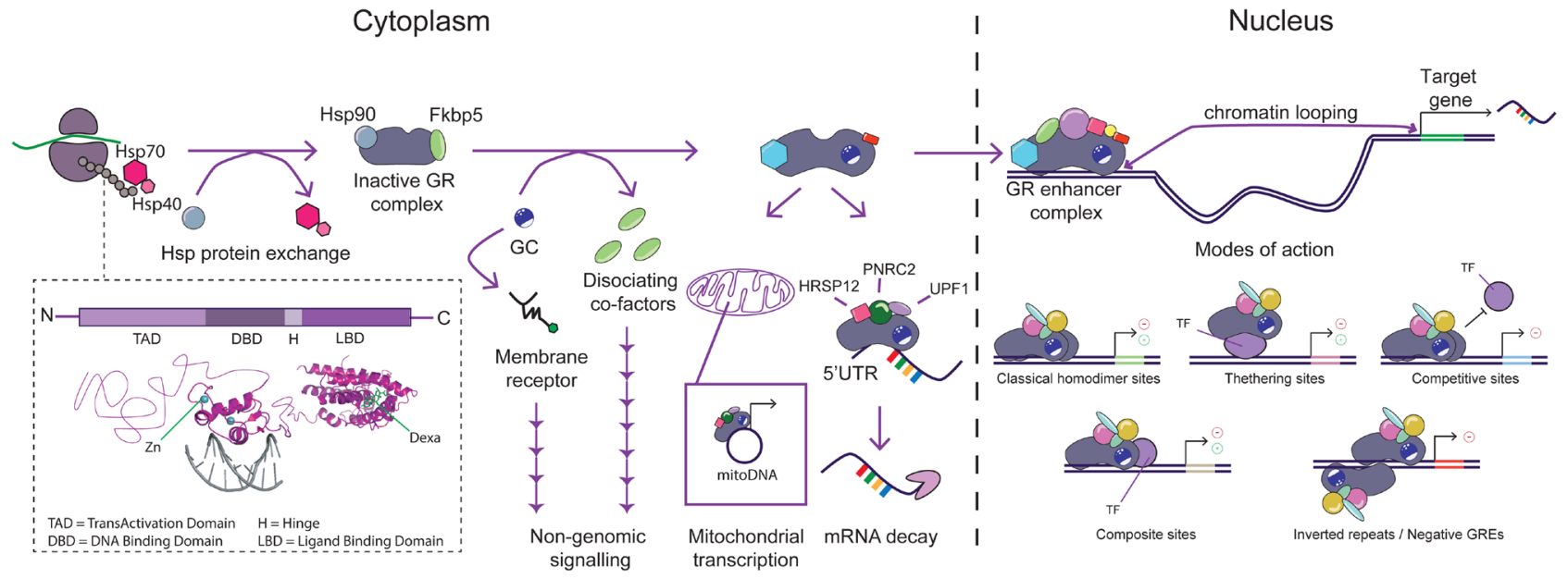

Figure 1

Molecular biology of the glucocorticoid receptor. The glucocorticoid receptor protein is translated in the cytoplasm and its folding is facilitated by the heat shock protein complex. In the process of maturation, an exchange of heat shock proteins and binding of FKBP5 occur. The inactive GR complex is now ready to bind the ligand which leads to structural changes, exposure of the nuclear localization sequence, and nuclear translocation. Once in the nucleus, the GR can bind a large number of genomic locations to ultimately regulate a large number of genes across the genome through numerous proposed mechanisms of action. In addition to the action of GR in the nucleus, GCs themselves or dissociation of interacting factors may lead to non-genomic signaling. Furthermore, GR can also regulate cell behavior through affecting mitochondrial transcription or mRNA decay. Data from Protein Data Base (https://www.rcsb.org); IDs 1R4O and 1P93. 
et al. 1988, Hard et al. 1990). The DNA-binding domain also contains the distal box (D box) with residues imperative for dimerization of the GR (Luisi et al. 1991, Watson et al. 2013). A flexible linker region, the hinge, is involved in nuclear translocation, transactivation, and structural flexibility of the GR dimer, enabling optimal contact with the GREs. The hinge contains various lysine residues that can be acetylated, leading to changes in GR activity output (Nader et al. 2009). For example, GR interaction with GREs is directly diminished by circadian transcription factor-mediated acetylation of the hinge region (Nader et al. 2009). After the hinge region, a highly hydrophobic part of the GR forms a ligand-binding pocket lined with both polar and nonpolar residues, containing space for interaction with endogenous or exogenous ligands. Upon ligand binding, various intradomain changes occur, and the activation function 2 (AF2) forms as the scaffold for protein interactions positioned over the ligand-binding pocket (Bledsoe et al. 2002).

\section{Versatility of glucocorticoid receptor action}

During protein translation and upon release from the ribosome, the GR protein folding will be initiated and facilitated by Hsp70-Hsp40 chaperone complex (Rexin et al. 1991, Scherrer et al. 1993, Smith \& Toft 1993, Morishima et al. 2000, Vandevyver et al. 2012) (Fig. 1). Subsequently, the Hop protein will enable the exchange of folding chaperones for Hsp90, and finally, recruitment of immunophilins will follow to complete the protein maturation process, increasing the affinity for the ligand (Chen \& Smith 1998, Morishima et al. 2000). Several kinases, including glycogen synthase kinase 3 (GSK3) and cyclin-dependent kinases, phosphorylate the GR upon ligand binding to alter GR confirmation and its interacting partner repertoire (Riggs et al. 2003), ultimately leading to the surface exposure of nuclear localization signal (Vandevyver et al. 2012). The GR-Hsp90-FKBP52-p23 complex tethers to dynein, an ATP-dependent motor protein that will move the complex along the microtubule cytoskeleton toward the nucleus. For nuclear translocation to occur, the nuclear localization signal will be recognized by importins which will facilitate GR-complex translocation to the nucleus (Picard \& Yamamoto 1987), through a well-described process reviewed elsewhere (Stewart 2007, Kim et al. 2017).

Upon ligand-induced translocation to the nucleus, the GR will stochastically and transiently interact with chromatin until it forms a weak-yet-stable GR-DNA interaction at its binding sites (Groeneweg et al. 2014). The sites that can be occupied by GR differ across cell types and are determined by various pioneer factors involved in regulating the accessibility of DNA, such as FOXA1 and GATA3 (So et al. 2007). In terms of genomic distribution, the majority of GR binding sites are found at distal enhancers, therefore, chromatin looping is necessary to bring these regulatory elements in close proximity to promoter regions of their target genes (D'Ippolito et al. 2018, McDowell et al. 2018) (Fig. 1). Once GR occupies its binding sites, it recruits diverse co-regulators, such as NCOA and NCOR proteins, that will enable either transcriptional activation or repression of gene expression across the genome (Xu et al. 1999).

The underlying mechanism by which GR associates with its binding sites can differ and can roughly be segregated into two groups: direct DNA binding or tethering to other DNA-resident transcription factors. The predominant mode of GR action, however, is through direct DNA binding of GR homodimer to its response elements (GRE; consensus sequence AGAACAnnnTGTTCT); 15 base-pair long motifs containing two inverted palindromic sequences separated by a 3 base-pair spacer (Luisi et al. 1991, Meijsing et al. 2009). Two GR monomers bind the opposing palindromic sequences in a head-to-tail fashion interacting through their dimerization surfaces found in proximity to the zinc fingers, forming hydrogen bonds that stabilize GR on DNA (Luisi et al. 1991).

In addition to DNA binding of GR as a homodimer, evidence exists that it can also directly bind DNA as a monomer (Schiller et al. 2014). This mode-ofaction entails GR binding to composite GREs, that is half sites (AGAACA/TGTTCT) in close genomic proximity to binding sites of other transcription factors, with which GR can interact and modulate their influence on target gene expression (Diamond et al. 1990, Schiller et al. 2014). GR monomers can also bind to negative GREs (nGREs), consisting of inverted repeats and a spacer sequence that varies from 0 to 2 nucleotides (CTCC $(\mathrm{N})_{0-2}$ GGAGA). At these inverted repeats, two GR monomers occupy opposite sides of the DNA, recruiting co-repressors (SMRT/ NCoR) and HDACs, and subsequently functioning as transcriptional repressors of nearby genes (Hudson et al. 2013). A study has found that under normal cortisol levels in mice, GR is preferentially bound to DNA as a monomer rather than as a dimer (Lim et al. 2015). However, upon treatment with a high dose of https://erc bioscientifica com https://doi.org/10.1530/ERC-20-0489 (c) 2021 Society for Endocrinology Published by Bioscientifica Ltd. Printed in Great Britain 
GCs, the monomers are removed from their half sites and dimer formation and assembly on classical GREs are observed (Lim et al. 2015).

Across the genome, GREs overlap with the DNA recognition sequences of other transcription factors. This results in competition for genome binding between GR and other factors, in which GR can impede the recruitment of other proteins to the DNA, leading to reduced expression of certain genes (Strömstedt et al. 1991, Subramaniam et al. 1998). Furthermore, evidence exists that in addition to direct DNA interaction, GR can alter transcription by tethering to other DNA-resident transcription factors (e.g. AP1, NF-kB, STAT) through protein-protein interactions (Biddie et al. 2011). By interacting with these factors, GR influences their DNA binding, interaction profile, ultimately affecting their target gene expression programs (Biddie et al. 2011, Tan \& Wahli 2016).

\section{Alternative modes of GR action}

Besides the classic mode of transcriptional control, GR has been suggested to have other modes of action (Fig. 1). In various in vitro models, fast, almost instant changes in various signaling cascades, including the PKC, Rho kinase, and PI3K/ATK, in response to GCs have been attributed to non-genomic actions (Panettieri et al. 2019). While there is limited evidence that cytosolic GR itself contributes to these (as argued in reviews covering the topic Desmet \& De Bosscher 2017, Scheschowitsch et al. 2017, Timmermans et al. 2019), the non-genomic actions are mostly being attributed to a membrane G-coupled receptor, which has an affinity to endogenous ligands (Orchinik et al. 1991) or a membrane-bound GR proposed to be generated through diverse mechanisms including alternative splicing (Vernocchi et al. 2013). In addition to that, some features of the non-genomic action (e.g. influence on the MAPK signaling) have been suggested to be mediated by the members of the cytoplasmic GR complex that dissociate upon ligand binding (Samarasinghe et al. 2011, Mitre-Aguilar et al. 2015).

Another facet of GR non-genomic action is its ability to regulate mitochondrial gene transcription. It has been shown that GR can be translocated to the mitochondria (Scheller et al. 2000, Moutsatsou et al. 2001) and actively bind GRE-like elements alone or in complex with other proteins in a hepatoma cell line and brain cells of rodent models (Du et al. 2009a,b, Psarra \& Sekeris 2011), in this way contributing to cellular energy metabolism regulation.
Additionally, it has been proposed that GR has the ability to bind the 5' untranslated region (UTR) of mRNA and regulate its stability. The ability of GR to elicit rapid mRNA degradation is afforded by ligand-induced recruitment of UPF1 in PNRC2-dependent fashion (Cho et al. 2015). Furthermore, the HRSP12 endoribonuclease has been reported as crucial for functionality of the active GR complex on mRNA (Park et al. 2016). Based on genome-wide analysis of transcripts affected by GR-mediated mRNA-decay, it is implied that these may be involved in various cellular processes, including immune response (Park et al. 2016).

\section{GR in cancer biology}

\section{Activation of GR as a potent therapeutic strategy in hematological cancers}

\section{GR action in immune cells}

The ability of GCs to suppress the immune system was initially harnessed for the treatment of rheumatoid arthritis (Hench \& Kendall 1949). The immune-suppressive action of GCs is underlined by acute inhibition of vascular permeability (Perretti \& Ahluwalia 2000), decrease in recruitment of leukocytes (Ince et al. 2018), and ultimately direct inhibition of cytokine release (Brattsand \& Linden 1996), alterations of differentiation, and block of migration. In terms of the molecular mechanism, trans-repression by monomeric GR was thought to be the main contributor to its immunosuppressive role (Smoak $\&$ Cidlowski 2004). The tethering process was proposed to negatively impact the gene expression of various proinflammatory molecules including interleukins, TNF- $\alpha$, interferon- $\gamma$, and cell adhesion proteins (Ratman et al. 2013, Xavier et al. 2016). However, this model has been challenged, illustrating that transactivation may be the main driver of immunosuppression by GR (reviewed in detail by Clark 2007). One example in support of the transactivation model comes from mice lacking a wellcharacterized direct GR-target gene DUSP1, which is regulated by GR homodimer formation on classical GREs. In these models, GCs were unable to inhibit zymosaninduced inflammation (Abraham et al. 2006) but still retained the immune-suppressive features in mast celldependent anaphylaxis (Maier et al. 2007). TSC22D3 gene, another gene regulated through GR binding to classical GREs, has also been implicated in immune suppression by GR as well as suppression of immunotherapy response by GCs in cancer (Ayroldi \& Riccardi 2009, Riccardi 2010, Yang et al. 2019). Importantly, a recent in-depth genomic 
study using mice with a mutation in GR-DBD that renders the protein unable to recognize DNA but still retain its tethering properties demonstrated that direct GR-DNA binding is essential for both transcriptional activation and repression on a genome-wide level (Escoter-Torres et al. 2020).

\section{GR agonists in the treatment of hematologic malignancies}

Activation of GR by synthetic GCs (e.g. dexamethasone, prednisone) is effectively being used in the treatment of hematologic malignancies. In various blood cancer types (acute and chronic lymphocytic leukemia, Hodgkin's lymphoma, multiple myeloma, and non-Hodgkin's lymphoma), GCs robustly induce tumor cell death (Kufe et al. 2006), through mechanisms further discussed below. However, despite reducing the disease burden, singleagent GCs do not lead to a prolonged delay in remission or complete cancer elimination (Pufall 2015). Consequently, various combination therapies have been developed and refined, drastically improving cure rates in children with leukemia. Today, phase treatment (remission induction, intensification, and maintenance) entails the use of GCs in combination with various other drugs (e.g. vincristine, asparaginase, methotrexate) in specific sequences clinically optimized to effectively eradicate cancer cells (Terwilliger \& Abdul-Hay 2017). In adult leukemia patients, however, phase treatment is less effective and cure rates are dismal (Pufall 2015).

\section{Mechanism of GC-induced apoptosis}

While details regarding specific components of GR-induced apoptosis in blood cancers are still unknown and appear dependent on cell lineage, activation of the intrinsic apoptotic pathway is required (Smith \& Cidlowski 2010). Mechanistically, it has been proposed that GR co-ordinates apoptosis entry threshold by regulating both anti- and pro-apoptotic genes (Ploner et al. 2008). Proapoptotic family members BIM and BMF are suggested to form a major part of GC response in leukemia cells (Ploner et al. 2008). In patient-derived xenograft models of acute lymphoblastic leukemia, GR regulation of BIM through a specific GR binding site within its intron has been found essential for GR-induced apoptosis, with the absence of binding correlating with dexamethasone resistance (Jing et al. 2015). In addition, downregulation of anti-apoptotic genes, such as BCL2, MCL1 and BCL2L1, seems to also be required for entry to apoptosis (Schmidt et al. 2006, Jing et al. 2015).

\section{Resistance to GC administration}

Due to high selection pressure applied by GC therapy, cancers of the lymphoid lineage often become refractory to this type of intervention. Various escape mechanisms have been reported (and extensively reviewed previously Scheijen 2019) including alternative splicing of the NR3C1 gene (Moalli et al. 1993, Rivers et al. 1999, Koga et al. 2005), inhibition of cell death through altered expression of key apoptotic genes or influence of stromal cells (Bachmann et al. 2005, Jiang et al. 2011, Ariës et al. 2014, Rosenthal \& Younes 2017), activation of survival signaling pathways such as PI3K/AKT and NOTCH1 (Real et al. 2009, Piovan et al. 2013, Revollo et al. 2013, Evangelisti et al. 2018), direct alteration of GR transcriptional output through reduced SWI/SNF chromatin remodeling complex expression (Pottier et al. 2008) or mutations in GR-complex auxiliary factors such as CREBBP and BTG1 (van Galen et al. 2010, Mullighan et al. 2011, Scheijen et al. 2017). Recently, integrative genomic analysis of acute lymphoblastic leukemia samples revealed CELSR2, a membrane-bound G-protein-coupled receptor, as a crucial component in GC therapy resistance (Autry et al. 2020). Knockdown of CELSR2 diminished GC response in human leukemia cell lines and revealed that Venetoclax, a potent $\mathrm{Bcl}-2$ inhibitor, synergistically restores sensitivity to GCs in mouse xenograft models (Autry et al. 2020).

\section{Dichotomy of GR action in solid cancers}

In non-hematological tumors, several studies support the involvement of GR in cancer development, aggressiveness, and therapy response. Studies have linked genetic changes (including copy number loss and single-nucleotide polymorphisms) of the NR3C1 gene to the development of various solid cancer types, including pituitary adenomas (Huizenga et al. 1998), colorectal carcinomas (Wildrick \& Boman 1988), gastric cancer (Gu et al. 2017), and breast cancer (Curran et al. 2001). Furthermore, the influence of GR on tumor biology is supported by carcinogeninduced cancer models in mice, where GCs protected against cancer development (Balansky et al. 2010). While in terms of tumorigenesis, most studies point toward a tumor-suppressive role of GR in solid cancers, GR action in solid cancer biology appears cancer-type dependent and influenced by treatment, as will be discussed below.

\section{Breast cancer}

GCs have a pivotal role in mammary gland physiology and development (Tronche et al. 1998, Wintermantel 
et al. 2005). Using mammary gland-specific GR-knockout mouse models, cell proliferation timing during lobuloalveolar development was shown to be dependent on GR (Wintermantel et al. 2005). While the GR protein is expressed in almost every cell type of the mammary gland, its expression is decreased during carcinogenesis (Perou et al. 2000, Sørlie et al. 2001, Lien et al. 2006, Conde et al. 2008, Buxant et al. 2010), suggesting a tumor-suppressive role in breast cancer. In line with this, numerous studies using in vitro models have linked GR activation by GCs to apoptosis regulation and cell proliferation in estrogen receptor- $\alpha(E R \alpha)$ positive breast cancer. Specifically, it is believed that GCs block the growth of breast cancer through inhibition of growth factor signaling (Osborne et al. 1979, Huff et al. 1988, Ewing et al. 1989, Gutierrez et al. 2005, Whyte et al. 2009). In addition, GCs also inhibit apoptosis by modulating the expression of apoptotic genes (Schorr \& Furth 2000, Mikosz et al. 2001, Wu et al. 2004) and interfering with p53 function (Moll et al. 1992, Sengupta et al. 2000). Of particular interest in luminal breast cancer is the interaction of GR and ER $\alpha$, that are shown to co-occupy the same genomic regions in clinical samples (Severson et al. 2018). Cross-talk between these two steroid hormone receptors has been reported to have favorable consequences in terms of prognosis (Abduljabbar et al. 2015). This is also supported by in vitro studies showing that GCs repress ERo-target genes involved in proliferation (Gong et al. 2008, Karmakar et al. 2013, West et al. 2016, Yang et al. 2017). It has been suggested that this negative regulation stems from direct inhibition of ER $\alpha$ enhancer function, accompanied by the loss of co-regulators and recruitment of repressors (Yang et al. 2017). The exact features of this negative regulation have previously been reviewed in-depth (Truong \& Lange 2018).

While a tumor-suppressive role of GR in ER $\alpha$-positive breast cancer is well-established, it was found that a specific breast cancer-associated cholesterol metabolite (cholesterol-5,6-epoxides, 6-oxo-cholestan-3 $\beta, 5 \alpha$-diol) may shift the role of GR toward oncogenic (Voisin et al. 2017). This cholesterol metabolite is able to bind to GR and alter its function, causing GR to regulate a different set of genes than with its physiological ligand (Voisin et al. 2017). For example, it was observed that while cortisolbound GR represses MMP1 gene expression, 6-oxocholestan-3 $\beta, 5 \alpha$-diol-bound GR increases its expression, suggesting GR function as an oncogene.

In breast cancer cells lacking expression of ER $\alpha$, GCs take on another role, supporting cancer growth and metastasis, and aggravating clinical aggressiveness (Pan et al. 2011, Abduljabbar et al. 2015, Chen et al.
2015, West et al. 2018). Activation of GR in ERo-negative disease supports an epithelial-to-mesenchymal (EMT) gene program, and GR expression levels have been associated with shorter relapse-free survival (Pan et al. 2011). Furthermore, a GR activity gene-signature specific for ER-negative breast cancer has recently been developed and associated with relapse despite administration of adjuvant chemotherapy (West et al. 2018). In support of these clinical observations, GR activation protects against apoptosis in in vitro and xenograft models (Wu et al. 2004, Pang et al. 2006) and inhibition of its signaling by mifepristone can augment chemotherapyinduced xenograft tumor shrinkage (Skor et al. 2013). It is proposed that this effect of GR is mediated through TEAD4, as pharmacological targeting of this transcription factor prevented GC-induced chemo-resistance in breast cancer models (He et al. 2019).

As mentioned above, studies have linked GR activation to EMT processes in ER-negative breast cancer. However, proof of functional consequence in terms of cancer metastatic potential was not reported until recently. Using xenograft models of ER-negative breast cancer, Obradović et al. (2019) demonstrated that activation of GR increased colonization and reduced survival of animal models. This was attributed to an increase in the expression of kinase ROR1, the ablation of which diminished metastatic outgrowth and prolonged survival of the mouse models used in the study (Obradović et al. 2019). These lines of evidence suggest that antagonism of the GR may be a viable strategy for increasing apoptosis chemotherapy efficacy in ER-negativebreastcancers, blocking metastatic spread. However, this hypothesis is yet to be tested in a clinical setting.

\section{Prostate cancer}

Prostate cancer is one of the most prevalent adult malignancies and the leading causes of cancer-related death in men (Siegel et al. 2019). This disease is driven by another steroid hormone receptor - the androgen receptor (AR) (Heinlein \& Chang 2004). The biology of primary prostate cancer vastly differs from the advanced, treatment-resistant disease (Prekovic et al. 2018a, Linder et al. 2018), and as discussed below, the GR function seems to also be altered during the course of disease progression.

In terms of primary prostate cancer, GR expression is lost in the transformation process of healthy epithelial prostate cells to cancer, suggesting that GR may act as a tumor suppressor in this context (Yemelyanov et al. 2007). In support of this, the overexpression of GR in anti-androgen sensitive LNCaP cell line model and 
GC-treatment caused a robust cell cycle exit, inhibition of proliferation and in vivo blockade of angiogenesis and tumor growth (Yano et al. 2006, Yemelyanov et al. 2007).

In contrast to primary prostate cancer, both GC- and GR-action are altered in advanced anti-androgen resistant disease. Several treatment-selected mutations in the AR cause expansion of ligand repertoire for this receptor (Prekovic et al. 2016, 2018b). The AR mutations L702H and T878A increase receptor affinity toward endogenous and synthetic GCs, which can now drive prostate cancer growth by promoting AR signaling (Zhao et al. 2000, Krishnan et al. 2002, Matias et al. 2002). While the mutant ARs can be activated by some of the clinically used GR agonists, they are unable to bind others, therefore, it has been clinically demonstrated that switch from one synthetic GR ligand to another can lead to a sufficient biomarker- and radiological-response (RomeroLaorden et al. 2018, Fenioux et al. 2019). A genomewide CRISPR-Cas9 KO screen revealed TLE3 loss to drive anti-androgen resistance in LNCaP prostate cancer cells, by allowing re-expression of GR expression in response to enzalutamide (anti-androgen) treatment (Palit et al. 2019). Once expressed, GR can bind to accessible AR sites and completely restore its transcriptional program in case of castration resistance prostate cancer (Arora et al. 2013). The latter is afforded by a metabolic adaptation through loss of cortisol catabolizing enzyme 11 $\beta$-hydroxysteroid dehydrogenase-2, leading to sustained levels of cortisol in the tumor cell surrounding, maintaining intratumoral GR constitutively active ( $\mathrm{Li}$ et al. 2017). While the preclinical evidence for GR 'take-over' is compelling, the only clinical trial reported to date has shown that addition of mifepristone to enzalutamide after a 12-week enzalutamide lead-in did not delay time to PSA progression (Serritella et al. 2020). However, additional clinical testing should be performed to conclusively determine whether GR inhibition may be used to combat anti-androgen resistance in advanced prostate cancer.

\section{Pancreatic cancer}

Human cortisol plays a critical role in pancreas development and function, contributing to the regulation of glucose homeostasis and nutrient metabolism. Both development and function of $\alpha$ - (Dumortier et al. 2011) and $\beta$-cells (Fine et al. 2018) of the pancreas are affected by GCs. Specifically, GR exerts its influence on glucagon secretion and insulin regulation of glycemia (reviewed by Rafacho et al. 2014). While the role of GC in the pathology of the pancreas is well-established and clinically exploited, it is still unclear to which extent
GCs contribute to pancreatic cancer biology. Currently, experimental evidence hints toward a tumor-suppressive action of GR in pancreatic cancer (Norman et al. 1994). This is also suggested by clinical data, as intraoperative dexamethasone administration may lead to improved survival in human pancreatic cancer patients (Call et al. 2015, Sandini et al. 2018). Specifically, using the multivariable Cox proportional hazard survival model, it was shown that patients who received intraoperative dexamethasone survived longer than patients not receiving this treatment (Call et al. 2015). Another study demonstrated that intraoperative dexamethasone slightly decreases infection complications and is independently associated with stage, pathologic characteristics and adjuvant therapy with improved overall survival in patients with pancreatic adenocarcinoma (Sandini et al. 2018). In line with this, GC-treatment blocks proliferation (Norman et al. 1994), invasiveness (Hirata et al. 1996) and leads to a reduction in IL-8 secretion (Egberts et al. 2008) in various pancreatic cancer cell line models. Furthermore, GCs diminished local recurrent tumor volume and the number of metastatic lesions in xenograft models (Egberts et al. 2008). The latter observation is further supported by a recent study showing that GCs inhibit the growth of patient-derived pancreatic cancer xenograft models through suppression of NF-kB, EMT, IL-6, and VEGF (Yao et al. 2020).

\section{Non-small cell lung cancer}

It is well established that GR is a crucial component in lung development, physiology, and disease, including cancer (extensively reviewed by Taylor et al. 2016). In context of non-small cell lung cancer, GR is a tumor suppressor as its gene expression strongly correlates with favorable overall and progression-free survival (Lu et al. 2006). In support of this, various in vitro and xenograft models have shown that GR activation in non-small lung cancer causes growth arrest (Taylor et al. 2016), but the direct mechanistic underpinnings thereof still remain elusive. The most compelling evidence for a tumor-suppressive role of GR in animal studies comes from cigar smoke-induced lung cancers, in which GC administration delayed cancer development and diminished cancer growth (Balansky et al. 2010). Despite promising preclinical results, the effect of GC monotherapy has not been established in the clinical setting (reviewed by Keith 2008), and the only clinical trial addressing the effect of GC-monotherapy on lung cancer was performed in the 1960s in patients with advanced lung cancer which showed no survival 
benefit. In support of the protective effect of GCs on lung cancer development, is an observational epidemiological study on chronic obstructive pulmonary disease, which reported that inhaled GC use is associated with lower lung cancer incidence (Parimon et al. 2007). Moreover, clinical trials have shown that in patients with lung lesions, GCs decrease the number of nodules detected by CT (van den Berg et al. 2008). Furthermore, pre-existing non-solid or partially solid nodules with a high chance of becoming cancerous, diminished in size following GC treatment (Veronesi et al. 2011).

\section{Ovarian cancer}

The interplay of cortisol and estradiol (E2) has been shown to be imperative for follicular development and ovulation (Breen et al. 2005). Specifically, cortisol has a direct effect on the ovary by affecting oocyte maturation, granulosa cell differentiation, steroidogenesis, and lipid metabolism (Breen et al. 2005, González et al. 2010, Simerman et al. 2015).

In ovarian cancer, high NR3C1 mRNA expression levels have been associated with aggressive clinical features (histologic subtype, higher grade, and advanced stage) and correlated with poor prognosis (Veneris et al. 2017), independently of BRCA mutation status (Veneris et al. 2019), suggesting that in this cancer type GR may act as a disease driver. It was observed that GC administration to ovarian cancer patients is followed by a rapid transcriptional response and upregulation of two anti-apoptotic GR-target genes, SGK1 and DUSP1, suggesting that GCs may decrease chemotherapy effectiveness in ovarian cancer (Melhem et al. 2009). In agreement with clinical data, various in vitro and xenograft studies have found that GR specifically diminishes sensitivity to chemotherapy-induced cell death. In ovarian cancer cell lines, GC-treatment induces the expression of a caspase inhibitor clAP2, which was essential for GR modulation of apoptosis sensitivity (Runnebaum \& Brüning 2005). Furthermore, in xenograft models, antagonistic targeting of GR restored sensitivity to chemotherapy-induced cell death by suppressing its survival signaling (Stringer-Reasor et al. 2015).

While GR activation may be deleterious in terms of chemotherapy response, evidence suggests that its signaling may be beneficial in suppressing the metastatic progression of ovarian cancer. Specifically, activation of GR leads to an increase in miR-708 expression, which targets Rap1B, necessary for integrin-mediated focal adhesion
(Lin et al. 2015). This in turn leads to impaired abdominal metastasis formation in an orthotopic xenograft mouse model (Lin et al. 2017). Jointly, these studies illustrate that GR may act in opposing fashions in ovarian cancer, diminishing metastatic progression while at the same time reducing response to chemotherapies.

\section{Endometrial cancer}

In healthy endometrial tissue, GR has an antagonistic role in relation to $E R \alpha$, opposing the growth-induction caused by ER $\alpha$ activation (Vahrenkamp et al. 2018). Clinical data imply that the function of GR is altered in endometrial cancer, specifically it has been reported that expression of GR in primary endometrial cancer is linked to disease aggressiveness and dismal prognosis (Tangen et al. 2017). This observation is supported by experimental data, showing that GCs do not oppose E2-induced proliferation in a cell line model of endometrial cancer (Vahrenkamp et al. 2018). In-depth molecular analysis of transcriptomes and DNA-binding landscapes of endometrial cancer models revealed that $\mathrm{ER} \alpha$ and GR co-operate to promote disease progression (Vahrenkamp et al. 2018). Mechanistically it is proposed that ER $\alpha$ may assist GR chromatin loading altering the genomic actions of GR and generating a unique transcriptome under dual activation. Of importance is the E2 and GC-induced downregulation of various cell adhesion genes which may contribute to an increase in the metastatic potential of endometrial cancers (Vahrenkamp et al. 2018).

\section{Other solid cancer types}

In addition to the cancer types discussed above, GR status or its activity have been associated with various biological features in other solid cancer types. Due to the lack of follow-up studies and mechanistic insights into the function of GR, we do not discuss these in further detail in this review. Nonetheless, high GR expression levels have been shown to correlate with favorable outcome in bladder cancer (Zheng et al. 2012, Ishiguro et al. 2014) and impairment of the GR-STAT5 axis in the liver has been reported to promote spontaneous hepatic tumorigenesis (Mueller et al. 2011). In contrast, high GR activity has been associated with an increase in proliferation in both metastatic colon cancer (Tian et al. 2019) and glioma (Langeveld et al. 1992). Further extensive research would be required to elucidate the biological impact of GR signaling, along with the clinical implications thereof, in these and other tumor types.
C) 2021 Society for Endocrinology Published by Bioscientifica Ltd. Printed in Great Britain 


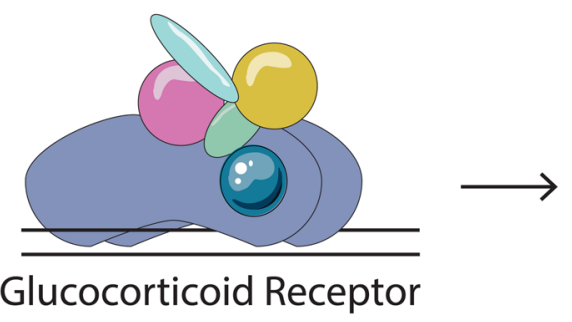

Glucocorticoid Receptor
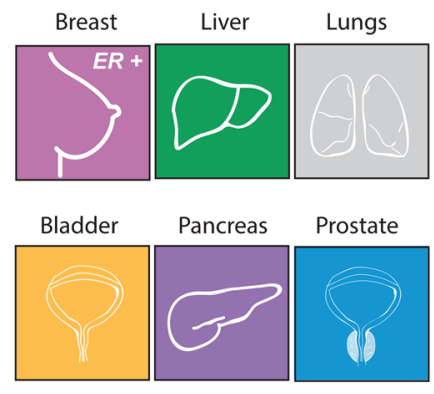

Tumor Supressive Features
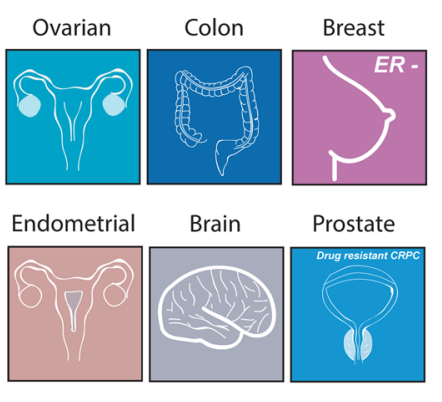

Oncogenic Features

Figure 2

Impact of GCs on various cancer types. The signaling related to glucocorticoid receptor activation may result in either tumor suppression or may facilitate tumor progression depending on the cancer type or disease setting.

\section{Conclusions}

While general features of GR response are well known and characterized, the biological consequences of its signaling across different cancers remain only superficially explored. In this review, we discuss the biological role of GR in various cancer types. Specifically, how GR can act either as a tumor suppressor, blocking growth and metastatic spread or as an oncogene, contributing to tumor progression depending on cancer type or disease setting (Fig. 2). It is still unknown what causes this duality of GR action in cancer and which underlying molecular players contribute to this. Furthermore, the oncogenic features GR activation may elicit seem to differ between cancer types, as is the case of ER $\alpha$-negative breast cancer and ovarian cancer. We speculate that changes in co-regulator repertoire, genetic mutations in GR gene itself, cross-talk with other steroid hormone receptors, activation by non-standard ligands, changes in chromatin accessibility, or activation of receptor kinase pathways may alter GR mode-of action pushing it toward tumor promotion in specific cancer types. Further genomic studies, in combination with functional screens, should be performed to better understand the difference between tumor suppressive and oncogenic GR signaling. Understanding these mechanisms may lead to the development of treatment strategies that rely on reverting GR to a tumor suppressor. It is tempting to suggest that cancer cells undergoing this GR-induced growth arrest may become reliant on other signaling pathways, which could potentially be targeted in a synergistic fashion.

Various synthetic GCs are used in clinical treatments of cancer, mostly to alleviate side effects without considering their effect on the tumor cells. Taking various studies into account on how GR activation in tumors can diminish chemo-response and increase metastatic potential, the impact of GC therapy should be reevaluated. While combating cancer therapy-related side effects are a necessity, patients may benefit from an altered strategy regarding GC treatment. It could also be interesting to design novel selective GR modulators (Meijer et al. 2018) that especially diminish the cancer therapy-related side-effects without having a negative impact on cancer progression. Moreover, long-term usage of GCs to treat certain diseases can result in reduced sensitivity or resistance to GCs, as well as hypersensitivity to GCs. Whether these differences in GC-response in the general population influence tumor development and progression, as well as cancer therapy response, remain to be further explored.

In conclusion, future research should shed light on these features of GC-response and could potentially lead to exciting discoveries that may be therapeutically exploited.

\section{Declaration of interest}

The authors declare that there is no conflict of interest that could be perceived as prejudicing the impartiality of this review.

\section{Funding}

This work was supported by the Netherlands Organization for Scientific Research NWO VIDI (91716401); an Alpe d'Huzes/KWF Bas Mulder Award; KWF (12128); and Oncode Institute.

\section{Author contribution statement}

Wilbert Zwart and Stefan Prekovic shared senior authorship.

\section{Acknowledgment}

In Figure 1, the authors have used the data deposited to Protein Data Base (https://www.rcsb.org) under the designated IDs 1R4O and 1 P93. (c) 2021 Society for Endocrinology Published by Bioscientifica Ltd. Printed in Great Britain 


\section{References}

Abduljabbar R, Negm OH, Lai CF, Jerjees DA, Al-Kaabi M, Hamed MR, Tighe PJ, Buluwela L, Mukherjee A, Green AR et al. 2015 Clinical and biological significance of glucocorticoid receptor (GR) expression in breast cancer. Breast Cancer Research and Treatment 150 335-346. (https://doi.org/10.1007/s10549-015-3335-1)

Abraham SM, Lawrence T, Kleiman A, Warden P, Medghalchi M, Tuckermann J, Saklatvala J \& Clark AR 2006 Antiinflammatory effects of dexamethasone are partly dependent on induction of dual specificity phosphatase 1. Journal of Experimental Medicine 203 1883-1889. (https://doi.org/10.1084/jem.20060336)

Ariës IM, Jerchel IS, Van Den Dungen RE, Van Den Berk LCJ, Boer JM, Horstmann MA, Escherich G, Pieters R \& den Boer ML 2014 EMP1, a novel poor prognostic factor in pediatric leukemia regulates prednisolone resistance, cell proliferation, migration and adhesion. Leukemia 28 1828-1837. (https://doi.org/10.1038/leu.2014.80)

Arora VK, Schenkein E, Murali R, Subudhi SK, Wongvipat J, Balbas MD, Shah N, Cai L, Efstathiou E, Logothetis C et al. 2013 Glucocorticoid receptor confers resistance to antiandrogens by bypassing androgen receptor blockade. Cell 155 1309-1322. (https://doi.org/10.1016/j. cell.2013.11.012)

Autry RJ, Paugh SW, Carter R, Shi L, Liu J, Ferguson DC, Lau CE, Bonten EJ, Yang W, McCorkle JR et al. 2020 Integrative genomic analyses reveal mechanisms of glucocorticoid resistance in acute lymphoblastic leukemia. Nature Cancer $1329-344$. (https://doi. org/10.1038/s43018-020-0037-3)

Ayroldi E \& Riccardi C 2009 Glucocorticoid-induced leucine zipper (GILZ): a new important mediator of glucocorticoid action. FASEB Journal 23 3649-3658. (https://doi.org/10.1096/fj.09-134684)

Bachmann PS, Gorman R, MacKenzie KL, Lutze-Mann L \& Lock RB 2005 Dexamethasone resistance in B-cell precursor childhood acute lymphoblastic leukemia occurs downstream of ligand-induced nuclear translocation of the glucocorticoid receptor. Blood $\mathbf{1 0 5}$ 2519-2526. (https://doi.org/10.1182/blood-2004-05-2023)

Baek SH \& Kim KIl 2014 Emerging roles of orphan nuclear receptors in cancer. Annual Review of Physiology 76 177-195. (https://doi. org/10.1146/annurev-physiol-030212-183758)

Balansky R, Ganchev G, Iltcheva M, Steele VE \& De Flora S 2010 Prevention of cigarette smoke-induced lung tumors in mice by budesonide, phenethyl isothiocyanate, and $\mathrm{N}$-acetylcysteine. International Journal of Cancer 126 1047-1054. (https://doi. org/10.1002/ijc.24942)

Biddie SC, John S, Sabo PJ, Thurman RE, Johnson TA, Schiltz RL, Miranda TB, Sung MH, Trump S, Lightman SL et al. 2011 Transcription factor AP1 potentiates chromatin accessibility and glucocorticoid receptor binding. Molecular Cell 43 145-155. (https:// doi.org/10.1016/j.molcel.2011.06.016)

Bledsoe RK, Montana VG, Stanley TB, Delves CJ, Apolito CJ, McKee DD, Consler TG, Parks DJ, Stewart EL, Willson TM et al. 2002 Crystal structure of the glucocorticoid receptor ligand binding domain reveals a novel mode of receptor dimerization and coactivator recognition. Cell 110 93-105 (https://doi.org/10.1016/s0092-8674(02)00817-6).

Brattsand R \& Linden M 1996 Cytokine modulation by glucocorticoids: mechanisms and actions in cellular studies. Alimentary Pharmacology and Therapeutics 10(Supplement 2) 81-90; discussion 91. (https://doi. org/10.1046/j.1365-2036.1996.22164025.x)

Breen KM, Billings HJ, Wagenmaker ER, Wessinger EW \& Karsch FJ 2005 Endocrine basis for disruptive effects of cortisol on preovulatory events. Endocrinology 146 2107-2115 (https://doi.org/10.1210/en.2004-1457).

Buxant F, Engohan-Aloghe C \& Noël JC 2010 Estrogen receptor, progesterone receptor, and glucocorticoid receptor expression in normal breast tissue, breast in situ carcinoma, and invasive breast cancer. Applied Immunohistochemistry and Molecular Morphology 18 254-257. (https://doi.org/10.1097/PAI.0b013e3181c10180)
Call TR, Pace NL, Thorup DB, Maxfield D, Chortkoff B, Christensen J \& Mulvihill SJ 2015 Factors associated with improved survival after resection of pancreatic adenocarcinoma: a multivariable model. Anesthesiology 122 317-324. (https://doi.org/10.1097/ ALN.0000000000000489)

Chen S \& Smith DF 1998 Hop as an adaptor in the heat shock protein 70 (Hsp70) and hsp90 chaperone machinery. Journal of Biological Chemistry 273 35194-35200. (https://doi.org/10.1074/jbc.273.52.35194)

Chen Z, Lan X, Wu D, Sunkel B, Ye Z, Huang J, Liu Z, Clinton SK, Jin VX \& Wang Q 2015 Ligand-dependent genomic function of glucocorticoid receptor in triple-negative breast cancer. Nature Communications 6 8323. (https://doi.org/10.1038/ncomms9323)

Cho H, Park OH, Park J, Ryu I, Kim J, Ko J \& Kim YK 2015 Glucocorticoid receptor interacts with PNRC2 in a ligand-dependent manner to recruit UPF1 for rapid mRNA degradation. PNAS 112 E1540-E1549. (https://doi.org/10.1073/pnas.1409612112)

Clark AR 2007 Anti-inflammatory functions of glucocorticoid-induced genes. Molecular and Cellular Endocrinology 275 79-97. (https://doi. org/10.1016/j.mce.2007.04.013)

Conde I, Paniagua R, Fraile B, Lucio J \& Arenas MI 2008 Glucocorticoid receptor changes its cellular location with breast cancer development. Histology and Histopathology 23 77-85. (https://doi. org/10.14670/hh-23.77)

Curran JE, Lea RA, Rutherford S, Weinstein SR \& Griffiths LR 2001 Association of estrogen receptor and glucocorticoid receptor gene polymorphisms with sporadic breast cancer. International Journal of Cancer 95 271-275. (https://doi.org/10.1002/10970215(20010720)95:4<271::aid-ijc1046>3.0.co;2-d)

D'Ippolito AM, McDowell IC, Barrera A, Hong LK, Leichter SM, Bartelt LC, Vockley CM, Majoros WH, Safi A, Song L et al. 2018 Preestablished chromatin interactions mediate the genomic response to glucocorticoids. Cell Systems 7 146-160.e7. (https://doi.org/10.1016/j. cels.2018.06.007)

Desmet SJ \& De Bosscher K 2017 Glucocorticoid receptors: finding the middle ground. Journal of Clinical Investigation 127 1136-1145. (https://doi.org/10.1172/JCI88886)

Diamond MI, Miner JN, Yoshinaga SK \& Yamamoto KR 1990 Transcription factor interactions: selectors of positive or negative regulation from a single DNA element. Science 249 1266-1272. (https://doi.org/10.1126/science.2119054)

Du J, McEwen B \& Manji HK 2009a Glucocorticoid receptors modulate mitochondrial function: A novel mechanism for neuroprotection. Communicative and Integrative Biology 2 350-352. (https://doi. org/10.4161/cib.2.4.8554)

Du J, Wang Y, Hunter R, Wei Y, Blumenthal R, Falke C, Khairova R, Zhou R, Yuan P, Machado-Vieira R et al. 2009b Dynamic regulation of mitochondrial function by glucocorticoids. PNAS $1063543-3548$. (https://doi.org/10.1073/pnas.0812671106)

Dumortier O, Theys N, Ahn MT, Remacle C \& Reusens B 2011 Impairment of rat fetal beta-cell development by maternal exposure to dexamethasone during different time-windows. PLOS ONE 6 e25576. (https://doi.org/10.1371/journal.pone.0025576)

Egberts JH, Schniewind B, Pätzold M, Kettler B, Tepel J, Kalthoff H \& Trauzold A 2008 Dexamethasone reduces tumor recurrence and metastasis after pancreatic tumor resection in SCID mice. Cancer Biology and Therapy 7 1044-1050. (https://doi.org/10.4161/ cbt.7.7.6099)

Escoter-Torres L, Greulich F, Quagliarini F, Wierer M \& Uhlenhaut NH 2020 Anti-inflammatory functions of the glucocorticoid receptor require DNA binding. Nucleic Acids Research 48 8393-8407. (https:// doi.org/10.1093/nar/gkaa565)

Evangelisti C, Cappellini A, Oliveira M, Fragoso R, Barata JT, Bertaina A, Locatelli F, Simioni C, Neri LM, Chiarini F et al. 2018 Phosphatidylinositol 3-kinase inhibition potentiates glucocorticoid response in B-cell acute lymphoblastic leukemia. Journal of Cellular Physiology 233 1796-1811. (https://doi.org/10.1002/jcp.26135)
(C) 2021 Society for Endocrinology Published by Bioscientifica Ltd. Printed in Great Britain 
Ewing TM, Murphy LJ, Ng ML, Pang GYN, Lee CSL, Watts CKW \& Sutherland RL 1989 Regulation of epidermal growth factor receptor by progestins and glucocorticoids in human breast cancer cell lines. International Journal of Cancer 44 744-752. (https://doi.org/10.1002/ ijc.2910440432)

Fenioux C, Louvet C, Charton E, Rozet F, Ropert S, Prapotnich D, Barret E, Sanchez-Salas R, Mombet A, Cathala N et al. 2019 Switch from abiraterone plus prednisone to abiraterone plus dexamethasone at asymptomatic PSA progression in patients with metastatic castration-resistant prostate cancer. BJU International 123 300-306. (https://doi.org/10.1111/bju.14511)

Fine NHF, Doig CL, Elhassan YS, Vierra NC, Marchetti P, Bugliani M, Nano R, Piemonti L, Rutter GA, Jacobson DA et al. 2018 Glucocorticoids reprogram $\beta$-cell signaling to preserve insulin secretion. Diabetes 67 278-290. (https://doi.org/10.2337/db16-1356)

Freedman LP, Luisi BF, Korszun ZR, Basavappa R, Sigler PB \& Yamamoto KR 1988 The function and structure of the metal coordination sites within the glucocorticoid receptor DNA binding domain. Nature 334 543-546. (https://doi.org/10.1038/334543a0)

Giguère V, Hollenberg SM, Rosenfeld MG \& Evans RM 1986 Functional domains of the human glucocorticoid receptor. Cell 46 645-652. (https://doi.org/10.1016/0092-8674(86)90339-9)

Gong H, Jarzynka MJ, Cole TJ, Lee JH, Wada T, Zhang B, Gao J, Song WC, DeFranco DB, Cheng SY et al. 2008 Glucocorticoids antagonize estrogens by glucocorticoid receptor-mediated activation of estrogen sulfotransferase. Cancer Research 68 7386-7393. (https:// doi.org/10.1158/0008-5472.CAN-08-1545)

González R, Ruiz-León Y, Gomendio M \& Roldan ERS 2010 The effect of glucocorticoids on ERK-1/2 phosphorylation during maturation of lamb oocytes and their subsequent fertilization and cleavage ability in vitro. Reproductive Toxicology 29 198-205. (https://doi. org/10.1016/j.reprotox.2009.10.009)

Groeneweg FL, van Royen ME, Fenz S, Keizer VIP, Geverts B, Prins J, de Kloet ER, Houtsmuller AB, Schmidt TS \& Schaaf MJM 2014 Quantitation of glucocorticoid receptor DNA-binding dynamics by single-molecule microscopy and FRAP. PLOS ONE 9 e90532. (https:// doi.org/10.1371/journal.pone.0090532)

Gronemeyer H \& Bourguet W 2009 Allosteric effects govern nuclear receptor action: DNA appears as a player. Science Signaling 2 pe34. (https://doi.org/10.1126/scisignal.273pe34)

Gu Y, Deng B, Kong J, Yan C, Huang T, Yang J, Wang Y, Wang T, Qi Q, Jin G et al. 2017 Functional polymorphisms in NR3C1 are associated with gastric cancer risk in Chinese population. Oncotarget 8 105312-105319. (https://doi.org/10.18632/oncotarget.22172) 29285253.

Gutierrez MC, Detre S, Johnston S, Mohsin SK, Shou J, Allred DC, Schiff R, Osborne CK \& Dowsett M 2005 Molecular changes in tamoxifenresistant breast cancer: relationship between estrogen receptor, HER-2, and p38 mitogen-activated protein kinase. Journal of Clinical Oncology 23 2469-2476. (https://doi.org/10.1200/JCO.2005.01.172)

Guyton AC \& Hall JE 2006 Textbook of medical physiology. Amsterdam, Netherland: Elsevier.

Hard T, Kellenbach E, Boelens R, Maler BA, Dahlman K, Freedman LP, Carlstedt-Duke J, Yamamoto KR, Gustafsson JA \& Kaptein R 1990 Solution structure of the glucocorticoid receptor DNA-binding domain. Science 249 157-160. (https://doi.org/10.1126/science.2115209)

He L, Yuan L, Sun Y, Wang P, Zhang H, Feng X, Wang Z, Zhang W, Yang C, Zeng YA et al. 2019 Glucocorticoid receptor signaling activates TEAD4 to promote breast cancer progression. Cancer Research 79 4399-4411. (https://doi.org/10.1158/0008-5472.CAN-19-0012)

Heinlein CA \& Chang C 2004 Androgen receptor in prostate cancer. Endocrine Reviews 25 276-308. (https://doi.org/10.1210/er.2002-0032)

Hench PS \& Kendall EC 1949 The effect of a hormone of the adrenal cortex (17-hydroxy-11-dehydrocorticosterone: Compound E) and of pituitary adrenocorticotropic hormone on rheumatoid arthritis; preliminary report. Proceedings of the Staff Meetings: Mayo Clinic $\mathbf{2 4}$ $181-197$.
Hirata M, Itoh M, Tsuchida A, Ooishi H, Hanada K \& Kajiyama G 1996 Dexamethasone inhibits invasiveness of a human pancreatic cancer cell line. International Journal of Oncology 8 327-330. (https://doi. org/10.3892/ijo.8.2.327)

Hollenberg SM \& Evans RM 1988 Multiple and cooperative transactivation domains of the human glucocorticoid receptor. Cell $\mathbf{5 5}$ 899-906. (https://doi.org/10.1016/0092-8674(88)90145-6)

Hollenberg SM, Weinberger C, Ong ES, Cerelli G, Oro A, Lebo R, Thompson EB, Rosenfeld MG \& Evans RM 1985 Primary structure and expression of a functional human glucocorticoid receptor cDNA. Nature 318 635-641. (https://doi.org/10.1038/318635a0)

Hudson WH, Youn C \& Ortlund EA 2013 The structural basis of direct glucocorticoid-mediated transrepression. Nature Structural and Molecular Biology 20 53-58. (https://doi.org/10.1038/nsmb.2456)

Huff KK, Knabbe C, Lindsey R, Kaufman D, Bronzed D, Lippman ME \& Dickson RB 1988 Multihormonal regulation of insulin-like growth factor-I-related protein in MCF-7 human breast cancer cells. Molecular Endocrinology 2 200-208. (https://doi.org/10.1210/mend-23-200)

Huizenga NATM, de Lange P, Koper JW, Clayton RN, Farrell WE, van der Lely AJ, Brinkmann AO, de Jong FH \& Lamberts SWJ 1998 Human adrenocorticotropin-secreting pituitary adenomas show frequent loss of heterozygosity at the glucocorticoid receptor gene locus. Journal of Clinical Endocrinology and Metabolism 83 917-921. (https://doi. org/10.1210/jcem.83.3.4648)

Ince LM, Weber J \& Scheiermann C 2018 Control of leukocyte trafficking by stress-associated hormones. Frontiers in Immunology 9 3143. (https://doi.org/10.3389/fimmu.2018.03143)

Ishiguro H, Kawahara T, Zheng Y, Netto GJ \& Miyamoto H 2014 Reduced glucocorticoid receptor expression predicts bladder tumor recurrence and progression. American Journal of Clinical Pathology 142 157-164. (https://doi.org/10.1309/AJCPU8UCEZYG4WTV)

Jiang N, Koh GS, Lim JY, Kham SK, Ariffin H, Chew FT \& Yeoh AE 2011 BIM is a prognostic biomarker for early prednisolone response in pediatric acute lymphoblastic leukemia. Experimental Hematology 39 321-9, 329.e1. (https://doi.org/10.1016/j.exphem.2010.11.009)

Jing D, Bhadri VA, Beck D, Thoms JAI, Yakob NA, Wong JWH, Knezevic K, Pimanda JE \& Lock RB 2015 Opposing regulation of BIM and BCL2 controls glucocorticoid-induced apoptosis of pediatric acute lymphoblastic leukemia cells. Blood 125 273-283. (https://doi. org/10.1182/blood-2014-05-576470)

Karmakar S, Jin Y \& Nagaich AK 2013 Interaction of glucocorticoid receptor (GR) with estrogen receptor (ER) $\alpha$ and activator protein 1 (AP1) in dexamethasone-mediated interference of ER $\alpha$ activity. Journal of Biological Chemistry 288 24020-24034. (https://doi. org/10.1074/jbc.M113.473819)

Keith BD 2008 Systematic review of the clinical effect of glucocorticoids on nonhematologic malignancy. BMC Cancer 8 84. (https://doi. org/10.1186/1471-2407-8-84)

Kim YH, Han ME \& Oh SO 2017 The molecular mechanism for nuclear transport and its application. Anatomy and Cell Biology 50 77-85. (https://doi.org/10.5115/acb.2017.50.2.77)

Koga Y, Matsuzaki A, Suminoe A, Hattori H, Kanemitsu S \& Hara T 2005 Differential mRNA expression of glucocorticoid receptor $\alpha$ and $\beta$ is associated with glucocorticoid sensitivity of acute lymphoblastic leukemia in children. Pediatric Blood and Cancer 45 121-127. (https:// doi.org/10.1002/pbc.20308)

Krishnan AV, Zhao XY, Swami S, Brive L, Peehl DM, Ely KR \& Feldman D 2002 A glucocorticoid-responsive mutant androgen receptor exhibits unique ligand specificity: therapeutic implications for androgen-independent prostate cancer. Endocrinology 143 1889-1900. (https://doi.org/10.1210/endo.143.5.8778)

Kufe DW, Holland JF \& Frei E 2006 Cancer Medicine 7. Hamilton, ON, Canada: BC Decker.

Langeveld CH, Van Waas MP, Stoof JC, Suianto W, De Kloet ER, Wolbers JG \& Heimans JJ 1992 Implication of glucocorticoid receptors in the stimulation of human glioma cell proliferation by 
dexamethasone. Journal of Neuroscience Research 31 524-531. (https:// doi.org/10.1002/jnr.490310316)

Li J, Alyamani M, Zhang A, Chang KH, Berk M, Li Z, Zhu Z, Petro M, Magi-Galluzzi C, Taplin ME et al. 2017 Aberrant corticosteroid metabolism in tumor cells enables GR takeover in enzalutamide resistant prostate cancer. eLife 6 e20183. (https://doi.org/10.7554/ eLife.20183)

Lien HC, Lu YS, Cheng AL, Chang WC, Jeng YM, Kuo YH, Huang CS, Chang KJ \& Yao YT 2006 Differential expression of glucocorticoid receptor in human breast tissues and related neoplasms. Journal of Pathology 209 317-327. (https://doi.org/10.1002/path.1982)

Lim HW, Uhlenhaut NH, Rauch A, Weiner J, Hübner S, Hübner N, Won KJ, Lazar MA, Tuckermann J \& Steger DJ 2015 Genomic redistribution of GR monomers and dimers mediates transcriptional response to exogenous glucocorticoid in vivo. Genome Research 25 836-844. (https://doi.org/10.1101/gr.188581.114)

Lin KT, Yeh YM, Chuang CM, Yang SY, Chang JW, Sun SP, Wang YS, Chao KC \& Wang LH 2015 Glucocorticoids mediate induction of microRNA-708 to suppress ovarian cancer metastasis through targeting Rap1B. Nature Communications 6 5917. (https://doi. org/10.1038/ncomms6917)

Lin KT, Sun SP, Wu JI \& Wang LH 2017 Low-dose glucocorticoids suppresses ovarian tumor growth and metastasis in an immunocompetent syngeneic mouse model. PLOS ONE 12 e0178937. (https://doi.org/10.1371/journal.pone.0178937)

Linder S, van der Poel HG, Bergman AM, Zwart W \& Prekovic S 2018 Enzalutamide therapy for advanced prostate cancer: efficacy, resistance and beyond. Endocrine-Related Cancer 26 R31-R52. (https:// doi.org/10.1530/ERC-18-0289)

Lu YS, Lien HC, Yeh PY, Kuo SH, Chang WC, Kuo ML \& Cheng AL 2006 Glucocorticoid receptor expression in advanced non-small cell lung cancer: clinicopathological correlation and in vitro effect of glucocorticoid on cell growth and chemosensitivity. Lung Cancer $\mathbf{5 3}$ 303-310. (https://doi.org/10.1016/j.lungcan.2006.05.005)

Luisi BF, Xu WX, Otwinowski Z, Freedman LP, Yamamoto KR \& Sigler PB 1991 Crystallographic analysis of the interaction of the glucocorticoid receptor with DNA. Nature 352 497-505. (https://doi. org/10.1038/352497a0)

Maier JV, Brema S, Tuckermann J, Herzer U, Klein M, Stassen M, Moorthy A \& Cato ACB 2007 Dual specificity phosphatase 1 knockout mice show enhanced susceptibility to anaphylaxis but are sensitive to glucocorticoids. Molecular Endocrinology 21 2663-2671. (https://doi.org/10.1210/me.2007-0067)

Markov GV \& Laudet V 2011 Origin and evolution of the ligandbinding ability of nuclear receptors. Molecular and Cellular Endocrinology 334 21-30. (https://doi.org/10.1016/j.mce.2010.10.017)

Matias PM, Carrondo MA, Coelho R, Thomaz M, Zhao XY, Wegg A, Crusius K, Egner U \& Donner P 2002 Structural basis for the glucocorticoid response in a mutant human androgen receptor (ARccr) derived from an androgen-independent prostate cancer. Journal of Medicinal Chemistry 45 1439-1446. (https://doi. org/10.1021/jm011072j)

Mazaira GI, Zgajnar NR, Lotufo CM, Daneri-Becerra C, Sivils JC, Soto OB, Cox MB \& Galigniana MD 2018 The nuclear receptor field: A historical overview and future challenges. Nuclear Receptor Research 5. (https://doi.org/10.11131/2018/101320)

McDowell IC, Barrera A, D'Ippolito AM, Vockley CM, Hong LK, Leichter SM, Bartelt LC, Majoros WH, Song L, Safi A et al. 2018 Glucocorticoid receptor recruits to enhancers and drives activation by motif-directed binding. Genome Research 28 1272-1284. (https:// doi.org/10.1101/gr.233346.117)

Meijer OC, Koorneef LL \& Kroon J 2018 Glucocorticoid receptor modulators. Annales d'Endocrinologie 79 107-111. (https://doi. org/10.1016/j.ando.2018.03.004)

Meijsing SH, Pufall MA, So AY, Bates DL, Chen L \& Yamamoto KR 2009 DNA binding site sequence directs glucocorticoid receptor structure and activity. Science 324 407-410. (https://doi.org/10.1126/ science.1164265)

Melhem A, Yamada SD, Fleming GF, Delgado B, Brickley DR, Wu W, Kocherginsky M \& Conzen SD 2009 Administration of glucocorticoids to ovarian cancer patients is associated with expression of the anti-apoptotic genes SGK1 and MKP1/DUSP1 in ovarian tissues. Clinical Cancer Research 15 3196-3204. (https://doi. org/10.1158/1078-0432.CCR-08-2131)

Mikosz CA, Brickley DR, Sharkey MS, Moran TW \& Conzen SD 2001 Glucocorticoid receptor-mediated protection from apoptosis is associated with induction of the serine/threonine survival kinase gene, sgk-1. Journal of Biological Chemistry 276 16649-16654. (https://doi.org/10.1074/jbc.M010842200)

Mitre-Aguilar IB, Cabrera-Quintero AJ \& Zentella-Dehesa A 2015 Genomic and non-genomic effects of glucocorticoids: implications for breast cancer. International Journal of Clinical and Experimental Pathology 8 1-10.

Moalli PA, Pillay S, Krett NL \& Rosen ST 1993 Alternatively spliced glucocorticoid receptor messenger RNAs in glucocorticoid-resistant human multiple myeloma cells. Cancer Research 53 3877-3879.

Moll UM, Riou G \& Levine AJ 1992 Two distinct mechanisms alter p53 in breast cancer: mutation and nuclear exclusion. PNAS $\mathbf{8 9}$ 7262-7266. (https://doi.org/10.1073/pnas.89.15.7262)

Morishima Y, Murphy PJM, Li DP, Sanchez ER \& Pratt WB 2000 Stepwise assembly of a glucocorticoid receptor- hsp90 heterocomplex resolves two sequential ATP-dependent events involving first hsp70 and then hsp90 in opening of the steroid binding pocket. Journal of Biological Chemistry 275 18054-18060. (https://doi.org/10.1074/jbc. M000434200)

Moutsatsou P, Psarra AM, Tsiapara A, Paraskevakou H, Davaris P \& Sekeris CE 2001 Localization of the glucocorticoid receptor in rat brain mitochondria. Archives of Biochemistry and Biophysics $\mathbf{3 8 6}$ 69-78. (https://doi.org/10.1006/abbi.2000.2162)

Mueller KM, Kornfeld JW, Friedbichler K, Blaas L, Egger G, Esterbauer H, Hasselblatt P, Schlederer M, Haindl S, Wagner KU et al. 2011 Impairment of hepatic growth hormone and glucocorticoid receptor signaling causes steatosis and hepatocellular carcinoma in mice. Hepatology 54 1398-1409. (https://doi.org/10.1002/hep.24509)

Mullighan CG, Zhang J, Kasper LH, Lerach S, Payne-Turner D, Phillips LA, Heatley SL, Holmfeldt L, Collins-Underwood JR, Ma J et al. 2011 Crebbp mutations in relapsed acute lymphoblastic leukaemia. Nature 471 235-239. (https://doi.org/10.1038/ nature09727)

Munck A \& Brinck-Johnsen T 1968 Specific and nonspecific physicochemical interactions of glucocorticoids and related steroids with rat thymus cells in vitro. Journal of Biological Chemistry $\mathbf{2 4 3}$ 5556-5565. (https://doi.org/10.1016/S0021-9258(18)91904-6)

Nader N, Chrousos GP \& Kino T 2009 Circadian rhythm transcription factor CLOCK regulates the transcriptional activity of the glucocorticoid receptor by acetylating its hinge region lysine cluster: potential physiological implications. FASEB Journal 23 1572-1583. (https://doi.org/10.1096/fj.08-117697)

Norman J, Franz M, Schiro R, Nicosia S, Docs J, Fabri PJ \& Gower Jr WR 1994 Functional glucocorticoid receptor modulates pancreatic carcinoma growth through an autocrine loop. Journal of Surgical Research 57 33-38. (https://doi.org/10.1006/jsre.1994.1105)

Obradović MMS, Hamelin B, Manevski N, Couto JP, Sethi A, Coissieux MM, Münst S, Okamoto R, Kohler H, Schmidt A et al. 2019 Glucocorticoids promote breast cancer metastasis. Nature $\mathbf{5 6 7}$ 540-544. (https://doi.org/10.1038/s41586-019-1019-4)

Orchinik M, Murray TF \& Moore FL 1991 A corticosteroid receptor in neuronal membranes. Science 252 1848-1851. (https://doi. org/10.1126/science.2063198)

Osborne CK, Monaco ME, Kahn CR, Huff K, Bronzert D \& Lippman ME 1979 Direct inhibition of growth and antagonism of insulin action by glucocorticoids in human breast cancer cells in culture. Cancer Research 39 2422-2428. https://erc bioscientifica com https://doi.org/10.1530/ERC-20-0489 (c) 2021 Society for Endocrinology Published by Bioscientifica Ltd. Printed in Great Britain 
Palit SAL, Vis D, Stelloo S, Lieftink C, Prekovic S, Bekers E, Hofland I, Šuštić T, Wolters L, Beijersbergen R et al. 2019 TLE3 loss confers AR inhibitor resistance by facilitating GR-mediated human prostate cancer cell growth. eLife 8 e47430. (https://doi.org/10.7554/ eLife.47430)

Pan D, Kocherginsky M \& Conzen SD 2011 Activation of the glucocorticoid receptor is associated with poor prognosis in estrogen receptor-negative breast cancer. Cancer Research 71 6360-6370. (https://doi.org/10.1158/0008-5472.CAN-11-0362)

Panettieri RA, Schaafsma D, Amrani Y, Koziol-White C, Ostrom R \& Tliba O 2019 Non-genomic effects of glucocorticoids: an updated view. Trends in Pharmacological Sciences 40 38-49. (https://doi. org/10.1016/j.tips.2018.11.002)

Pang D, Kocherginsky M, Krausz T, Kim SY \& Conzen SD 2006 Dexamethasone decreases xenograft response to paclitaxel through inhibition of tumor cell apoptosis. Cancer Biology and Therapy 5 933-940. (https://doi.org/10.4161/cbt.5.8.2875)

Parimon T, Chien JW, Bryson CL, McDonell MB, Udris EM \& Au DH 2007 Inhaled corticosteroids and risk of lung cancer among patients with chronic obstructive pulmonary disease. American Journal of Respiratory and Critical Care Medicine 175 712-719. (https://doi. org/10.1164/rccm.200608-1125OC)

Park OH, Park J, Yu M, An HT, Ko J \& Kim YK 2016 Identification and molecular characterization of cellular factors required for glucocorticoid receptor-mediated mRNA decay. Genes and Development 30 2093-2105. (https://doi.org/10.1101/gad.286484.116)

Perou CM, Sørlie T, Eisen MB, Van De Rijn M, Jeffrey SS, Rees CA, Pollack JR, Ross DT, Johnsen H, Akslen LA et al. 2000 Molecular portraits of human breast tumours. Nature 406 747-752. (https://doi. org $/ 10.1038 / 35021093)$

Perretti M \& Ahluwalia A 2000 The microcirculation and inflammation: site of action for glucocorticoids. Microcirculation 7 147-161. (https:// doi.org/10.1111/j.1549-8719.2000.tb00117.x)

Picard D \& Yamamoto KR 1987 Two signals mediate hormone-dependent nuclear localization of the glucocorticoid receptor. EMBO Journal 6 3333-3340. (https://doi. org/10.1002/j.1460-2075.1987.tb02654.x)

Piovan E, Yu J, Tosello V, Herranz D, Ambesi-Impiombato A, Da Silva AC, Sanchez-Martin M, Perez-Garcia A, Rigo I, Castillo M et al. 2013 Direct reversal of glucocorticoid resistance by AKT inhibition in acute lymphoblastic leukemia. Cancer Cell 24 766-776. (https:// doi.org/10.1016/j.ccr.2013.10.022)

Ploner C, Rainer J, Niederegger H, Eduardoff M, Villunger A, Geley S \& Kofler R 2008 The BCL2 rheostat in glucocorticoid-induced apoptosis of acute lymphoblastic leukemia. Leukemia 22 370-377. (https://doi. org/10.1038/sj.leu.2405039)

Pottier N, Yang W, Assem M, Panetta JC, Pei D, Paugh SW, Cheng C, Den Boer ML, Relling MV, Pieters R et al. 2008 The SWI/SNF chromatin-remodeling complex and glucocorticoid resistance in acute lymphoblastic leukemia. Journal of the National Cancer Institute 100 1792-1803. (https://doi.org/10.1093/jnci/djn416)

Prekovic S, van Royen ME, Voet ARD, Geverts B, Houtman R, Melchers D, Zhang KYJ, Van den Broeck T, Smeets E, Spans L et al. 2016 The effect of F877L and T878A mutations on androgen receptor response to enzalutamide. Molecular Cancer Therapeutics $\mathbf{1 5}$ 1702-1712. (https://doi.org/10.1158/1535-7163.MCT-15-0892)

Prekovic S, Van den Broeck T, Linder S, van Royen ME, Houtsmuller AB, Handle F, Joniau S, Zwart W \& Claessens F 2018a Molecular underpinnings of enzalutamide resistance. Endocrine-Related Cancer 25 R545-R557. (https://doi.org/10.1530/ERC-17-0136)

Prekovic S, Van den Broeck T, Moris L, Smeets E, Claessens F, Joniau S, Helsen C \& Attard G 2018b Treatment-induced changes in the androgen receptor axis: liquid biopsies as diagnostic/prognostic tools for prostate cancer. Molecular and Cellular Endocrinology 462 56-63. (https://doi.org/10.1016/j.mce.2017.08.020)
Psarra AM \& Sekeris CE 2011 Glucocorticoids induce mitochondrial gene transcription in HepG2 cells: role of the mitochondrial glucocorticoid receptor. Biochimica et Biophysica Acta 1813 1814-1821. (https://doi.org/10.1016/j.bbamcr.2011.05.014)

Pufall MA 2015 Glucocorticoids and cancer. Advances in Experimental Medicine and Biology 872 315-333. (https://doi.org/10.1007/978-14939-2895-8_14)

Rafacho A, Ortsäter H, Nadal A \& Quesada I 2014 Glucocorticoid treatment and endocrine pancreas function: implications for glucose homeostasis, insulin resistance and diabetes. Journal of Endocrinology 223 R49-R62. (https://doi.org/10.1530/JOE-14-0373)

Ratman D, Berghe W Vanden, Dejager L, Libert C, Tavernier J, Beck IM \& De Bosscher K 2013 How glucocorticoid receptors modulate the activity of other transcription factors: a scope beyond tethering. Molecular and Cellular Endocrinology 380 41-54. (https://doi. org/10.1016/j.mce.2012.12.014)

Real PJ, Tosello V, Palomero T, Castillo M, Hernando E, De Stanchina E, Sulis ML, Barnes K, Sawai C, Homminga I et al. $2009 \gamma$-secretase inhibitors reverse glucocorticoid resistance in $\mathrm{T}$ cell acute lymphoblastic leukemia. Nature Medicine 15 50-58. (https://doi. org/10.1038/nm.1900)

Revollo JR, Oakley RH, Lu NZ, Kadmiel M, Gandhavadi M \& Cidlowski JA 2013 HES1 is a master regulator of glucocorticoid receptor-dependent gene expression. Science Signaling 6 ra103-ra103. (https://doi.org/10.1126/scisignal.2004389)

Rexin M, Busch W \& Gehring U 1991 Protein components of the nonactivated glucocorticoid receptor. Journal of Biological Chemistry 266 24601-24605. (https://doi.org/10.1016/S0021-9258(18)54271-X)

Riccardi C 2010 GILZ (glucocorticoid-induced leucine zipper), a mediator of the anti-inflammatory and immunosuppressive activity of glucocorticoids. Annali di Igiene 22 (Supplement 1) 53-59.

Riggs DL, Roberts PJ, Chirillo SC, Cheung-Flynn J, Prapapanich V, Ratajczak T, Gaber R, Picard D \& Smith DF 2003 The Hsp90-binding peptidylprolyl isomerase FKBP52 potentiates glucocorticoid signaling in vivo. EMBO Journal 22 1158-1167. (https://doi. org/10.1093/emboj/cdg108)

Rivers C, Levy A, Hancock J, Lightman S \& Norman M 1999 Insertion of an amino acid in the DNA-binding domain of the glucocorticoid receptor as a result of alternative splicing. Journal of Clinical Endocrinology and Metabolism 84 4283-4286. (https://doi. org/10.1210/jcem.84.11.6235)

Romero-Laorden N, Lozano R, Jayaram A, López-Campos F, Saez MI, Montesa A, Gutierrez-Pecharoman A, Villatoro R, Herrera B, Correa R et al. 2018 Phase II pilot study of the prednisone to dexamethasone switch in metastatic castration-resistant prostate cancer (mCRPC) patients with limited progression on abiraterone plus prednisone (SWITCH study). British Journal of Cancer 119 1052-1059. (https:// doi.org/10.1038/s41416-018-0123-9)

Rosenthal A \& Younes A 2017 High grade B-cell lymphoma with rearrangements of MYC and BCL2 and/or BCL6: double hit and triple hit lymphomas and double expressing lymphoma. Blood Reviews 31 37-42. (https://doi.org/10.1016/j.blre.2016.09.004)

Runnebaum IB \& Brüning A 2005 Glucocorticoids inhibit cell death in ovarian cancer and up-regulate caspase inhibitor cIAP2. Clinical Cancer Research 11 6325-6332. (https://doi.org/10.1158/1078-0432. CCR-05-0182)

Samarasinghe RA, Di Maio R, Volonte D, Galbiati F, Lewis M, Romero G \& DeFranco DB 2011 Nongenomic glucocorticoid receptor action regulates gap junction intercellular communication and neural progenitor cell proliferation. PNAS 108 16657-16662. (https://doi. org/10.1073/pnas.1102821108)

Sandini M, Ruscic KJ, Ferrone CR, Warshaw AL, Qadan M, Eikermann M, Lillemoe KD \& Fernández-del Castillo C 2018 Intraoperative dexamethasone decreases infectious complications after pancreaticoduodenectomy and is associated with long-term survival https://erc.bioscientifica.com

https://doi.org/10.1530/ERC-20-0489 c) 2021 Society for Endocrinology Published by Bioscientifica Ltd. Printed in Great Britain 
in pancreatic cancer. Annals of Surgical Oncology 25 4020-4026. (https://doi.org/10.1245/s10434-018-6827-5)

Scheijen B 2019 Molecular mechanisms contributing to glucocorticoid resistance in lymphoid malignancies. Cancer Drug Resistance $\mathbf{2}$ 647-664. (https://doi.org/10.20517/cdr.2019.29)

Scheijen B, Boer JM, Marke R, Tijchon E, van Ingen Schenau D, Waanders E, van Emst L, van der Meer LT, Pieters R, Escherich G et al. 2017 Tumor suppressors BTG1 and IKZF1 cooperate during mouse leukemia development and increase relapse risk in B-cell precursor acute lymphoblastic leukemia patients. Haematologica 102 541-551. (https://doi.org/10.3324/haematol.2016.153023)

Scheller K, Sekeris CE, Krohne G, Hock R, Hansen IA \& Scheer U 2000 Localization of glucocorticoid hormone receptors in mitochondria of human cells. European Journal of Cell Biology 79 299-307. (https:// doi.org/10.1078/S0171-9335(04)70033-3)

Scherrer LC, Picard D, Massa E, Harmon JM, Simons Jr SS, Yamamoto KR \& Pratt WB 1993 Evidence that the hormone binding domain of steroid receptors confers hormonal control on chimeric proteins by determining their hormone-regulated binding to heat-shock protein 90. Biochemistry 32 5381-5386. (https://doi.org/10.1021/bi00071a013)

Scheschowitsch K, Leite JA \& Assreuy J 2017 New insights in glucocorticoid receptor signaling-more than just a ligand binding receptor. Frontiers in Endocrinology 8 16. (https://doi.org/10.3389/ fendo.2017.00016)

Schiller BJ, Chodankar R, Watson LC, Stallcup MR \& Yamamoto KR 2014 Glucocorticoid receptor binds half sites as a monomer and regulates specific target genes. Genome Biology 15 418. (https://doi. org/10.1186/s13059-014-0418-y)

Schmidt S, Rainer J, Riml S, Ploner C, Jesacher S, Achmüller C, Presul E, Skvortsov S, Crazzolara R, Fiegl M et al. 2006 Identification of glucocorticoid-response genes in children with acute lymphoblastic leukemia. Blood 107 2061-2069. (https://doi.org/10.1182/blood2005-07-2853)

Schorr K \& Furth PA 2000 Induction of bcl-xL expression in mammary epithelial cells is glucocorticoid-dependent but not signal transducer and activator of transcription 5-dependent. Cancer Research $\mathbf{6 0}$ 5950-5953.

Sengupta S, Vonesch JL, Waltzinger C, Zheng H \& Wasylyk B 2000 Negative cross-talk between p53 and the glucocorticoid receptor and its role in neuroblastoma cells. EMBO Journal 19 6051-6064 (https:// doi.org/10.1093/emboj/19.22.6051).

Serritella A, Shevrin DH, Heath EI, Wade JL, Martinez E, Karrison T, Stadler WM \& Szmulewitz RZ 2020 Phase I/II trial of enzalutamide (Enz) plus mifepristone (Mif) for metastatic castration-resistant prostate cancer (mCRPC). Journal of Clinical Oncology 38 91-91. (https://doi.org/10.1200/JCO.2020.38.6_suppl.91)

Severson TM, Kim Y, Joosten SEP, Schuurman K, Van Der Groep P, Moelans CB, Ter Hoeve ND, Manson QF, Martens JW, Van Deurzen CHM et al. 2018 Characterizing steroid hormone receptor chromatin binding landscapes in male and female breast cancer. Nature Communications 9 482. (https://doi.org/10.1038/s41467-018-02856-2)

Siegel RL, Miller KD \& Jemal A 2019 Cancer statistics, 2019. CA 201969 7-34. (https://doi.org/10.3322/caac.21551)

Simerman AA, Hill DL, Grogan TR, Elashoff D, Clarke NJ, Goldstein EH, Manrriquez AN, Chazenbalk GD \& Dumesic DA 2015 Intrafollicular cortisol levels inversely correlate with cumulus cell lipid content as a possible energy source during oocyte meiotic resumption in women undergoing ovarian stimulation for in vitro fertilization. Fertility and Sterility 103 249-257. (https://doi.org/10.1016/j.fertnstert.2014.09.034)

Skor MN, Wonder EL, Kocherginsky M, Goyal A, Hall BA, Cai Y \& Conzen SD 2013 Glucocorticoid receptor antagonism as a novel therapy for triple-negative breast cancer. Clinical Cancer Research 19 6163-6172. (https://doi.org/10.1158/1078-0432.CCR-12-3826)

Smith DF \& Toft DO 1993 Steroid receptors and their associated proteins. Molecular Endocrinology 7 4-11. (https://doi.org/10.1210/ mend.7.1.8446107)
Smith LK \& Cidlowski JA 2010 Glucocorticoid-induced apoptosis of healthy and malignant lymphocytes. Progress in Brain Research 182 1-30. (https://doi.org/10.1016/S0079-6123(10)82001-1)

Smoak KA \& Cidlowski JA 2004 Mechanisms of glucocorticoid receptor signaling during inflammation. Mechanisms of Ageing and Development 125 697-706. (https://doi.org/10.1016/j.mad.2004.06.010)

So AY-L, Chaivorapol C, Bolton EC, Li H \& Yamamoto KR 2007 Determinants of cell-and gene-specific transcriptional regulation by the glucocorticoid receptor. PLoS Genetics 3 e94. (https://doi. org/10.1371/journal.pgen.0030094)

Sørlie T, Perou CM, Tibshirani R, Aas T, Geisler S, Johnsen H, Hastie T, Eisen MB, Van De Rijn M, Jeffrey SS et al. 2001 Gene expression patterns of breast carcinomas distinguish tumor subclasses with clinical implications. PNAS 98 10869-10874. (https://doi. org/10.1073/pnas.191367098)

Stewart M 2007 Molecular mechanism of the nuclear protein import cycle. Nature Reviews. Molecular Cell Biology 8 195-208. (https://doi. org/10.1038/nrm2114)

Stringer-Reasor EM, Baker GM, Skor MN, Kocherginsky M, Lengyel E, Fleming GF \& Conzen SD 2015 Glucocorticoid receptor activation inhibits chemotherapy-induced cell death in high-grade serous ovarian carcinoma. Gynecologic Oncology 138 656-662. (https://doi. org/10.1016/j.ygyno.2015.06.033)

Strömstedt PE, Poellinger L, Gustafsson JA \& Carlstedt-Duke J 1991 The glucocorticoid receptor binds to a sequence overlapping the TATA box of the human osteocalcin promoter: a potential mechanism for negative regulation. Molecular and Cellular Biology 11 3379-3383. (https://doi.org/10.1128/mcb.11.6.3379)

Subramaniam N, Cairns W \& Okret S 1998 Glucocorticoids repress transcription from a negative glucocorticoid response element recognized by two homeodomain-containing proteins, Pbx and Oct1. Journal of Biological Chemistry 273 23567-23574. (https://doi. org/10.1074/jbc.273.36.23567)

Tan CK \& Wahli W 2016 A trilogy of glucocorticoid receptor actions. PNAS 113 1115-1117. (https://doi.org/10.1073/pnas.1524215113)

Tangen IL, Veneris JT, Halle MK, Werner HM, Trovik J, Akslen LA, Salvesen HB, Conzen SD, Fleming GF \& Krakstad C 2017 Expression of glucocorticoid receptor is associated with aggressive primary endometrial cancer and increases from primary to metastatic lesions. Gynecologic Oncology 147 672-677. (https://doi.org/10.1016/j. ygyno.2017.09.013)

Taylor KM, Ray DW \& Sommer P 2016 Glucocorticoid receptors in lung cancer: new perspectives. Journal of Endocrinology 229 R17-R28. (https://doi.org/10.1530/JOE-15-0496)

Terwilliger T \& Abdul-Hay M 2017 Acute lymphoblastic leukemia: a comprehensive review and 2017 update. Blood Cancer Journal 7 e577-e577. (https://doi.org/10.1038/bcj.2017.53)

Thornton JW 2001 Evolution of vertebrate steroid receptors from an ancestral estrogen receptor by ligand exploitation and serial genome expansions. PNAS 98 5671-5676. (https://doi.org/10.1073/ pnas.091553298)

Tian D, Tian M, Han G \& Li JL 2019 Increased glucocorticoid receptor activity and proliferation in metastatic colon cancer. Scientific Reports 9 11257. (https://doi.org/10.1038/s41598-019-47696-2)

Timmermans S, Souffriau JB \& Libert C 2019 A general introduction to glucocorticoid biology. Frontiers in Immunology 10 1545. (https://doi. org/10.3389/fimmu.2019.01545)

Tronche F, Kellendonk C, Reichardt HM \& Schütz G 1998 Genetic dissection of glucocorticoid receptor function in mice. Current Opinion in Genetics and Development 8 532-538. (https://doi. org/10.1016/s0959-437x(98)80007-5)

Truong TH \& Lange CA 2018 Deciphering steroid receptor crosstalk in hormone-driven cancers. Endocrinology 159 3897-3907. (https://doi. org/10.1210/en.2018-00831)

Vahrenkamp JM, Yang $\mathrm{CH}$, Rodriguez AC, Almomen A, Berrett KC, Trujillo AN, Guillen KP, Welm BE, Jarboe EA, Janat-Amsbury MM 
et al. 2018 Clinical and genomic crosstalk between glucocorticoid receptor and estrogen receptor $\alpha$ in endometrial cancer. Cell Reports 22 2995-3005. (https://doi.org/10.1016/j.celrep.2018.02.076)

van den Berg RM, Teertstra HJ, van Zandwijk N, van Tinteren $\mathrm{H}$, Visser C, Pasic A, Sutedja TG, Baas P, Golding RP, Postmus PE et al. 2008 CT detected indeterminate pulmonary nodules in a chemoprevention trial of fluticasone. Lung Cancer 60 57-61. (https:// doi.org/10.1016/j.lungcan.2007.09.007)

van Galen JC, Kuiper RP, van Emst L, Levers M, Tijchon E, Scheijen B, Waanders E, van Reijmersdal SV, Gilissen C \& van Kessel AG 2010 BTG1 regulates glucocorticoid receptor autoinduction in acute lymphoblastic leukemia. Blood 115 4810-4819. (https://doi. org/10.1182/blood-2009-05-223081)

Vandevyver S, Dejager L \& Libert C 2012 On the trail of the glucocorticoid receptor: into the nucleus and back. Traffic $\mathbf{1 3}$ 364-374. (https://doi.org/10.1111/j.1600-0854.2011.01288.x)

Vandevyver S, Dejager L \& Libert C 2014 Comprehensive overview of the structure and regulation of the glucocorticoid receptor. Endocrine Reviews 35 671-693. (https://doi.org/10.1210/er.20141010)

Veneris JT, Darcy KM, Mhawech-Fauceglia P, Tian C, Lengyel E, Lastra RR, Pejovic T, Conzen SD \& Fleming GF 2017 High glucocorticoid receptor expression predicts short progression-free survival in ovarian cancer. Gynecologic Oncology 146 153-160. (https://doi.org/10.1016/j.ygyno.2017.04.012)

Veneris JT, Huang L, Churpek JE, Conzen SD \& Fleming GF 2019 Glucocorticoid receptor expression is associated with inferior overall survival independent of BRCA mutation status in ovarian cancer. International Journal of Gynecological Cancer 29 357-364. (https://doi. org/10.1136/ijgc-2018-000101).

Vernocchi S, Battello N, Schmitz S, Revets D, Billing AM, Turner JD \& Muller CP 2013 Membrane glucocorticoid receptor activation induces proteomic changes aligning with classical glucocorticoid effects. Molecular and Cellular Proteomics 12 1764-1779. (https://doi. org/10.1074/mcp.M112.022947)

Veronesi G, Szabo E, DeCensi A, Guerrieri-Gonzaga A, Bellomi M, Radice D, Ferretti S, Pelosi G, Lazzeroni M, Serrano D et al. 2011 Randomized phase II trial of inhaled budesonide versus placebo in high-risk individuals with CT screen-detected lung nodules. Cancer Prevention Research 4 34-42. (https://doi.org/10.1158/1940-6207.CAPR-10-0182)

Voisin M, de Medina P, Mallinger A, Dalenc F, Huc-Claustre E, Leignadier J, Serhan N, Soules R, Ségala G, Mougel A et al. 2017 Identification of a tumor-promoter cholesterol metabolite in human breast cancers acting through the glucocorticoid receptor. PNAS 114 E9346-E9355. (https://doi.org/10.1073/pnas.1707965114)

Watson LC, Kuchenbecker KM, Schiller BJ, Gross JD, Pufall MA \& Yamamoto KR 2013 The glucocorticoid receptor dimer interface allosterically transmits sequence-specific DNA signals. Nature Structural and Molecular Biology 20 876-883. (https://doi.org/10.1038/ nsmb.2595)

West DC, Pan D, Tonsing-Carter EY, Hernandez KM, Pierce CF, Styke SC, Bowie KR, Garcia TI, Kocherginsky M \& Conzen SD 2016 GR and ER coactivation alters the expression of differentiation genes and associates with improved ER+ breast cancer outcome. Molecular Cancer Research 14 707-719. (https://doi.org/10.1158/1541-7786.MCR-15-0433)

West DC, Kocherginsky M, Tonsing-Carter EY, Dolcen DN, Hosfield DJ, Lastra RR, Sinnwell JP, Thompson KJ, Bowie KR, Harkless RV et al. 2018 Discovery of a glucocorticoid receptor (GR) activity signature using selective GR antagonism in ER-negative breast cancer. Clinical Cancer Research 24 3433-3446. (https://doi.org/10.1158/1078-0432. CCR-17-2793)
Whirledge S \& DeFranco DB 2018 Glucocorticoid signaling in health and disease: insights from tissue-specific GR knockout mice. Endocrinology 159 46-64. (https://doi.org/10.1210/en.2017-00728)

Whyte J, Bergin O, Bianchi A, McNally S \& Martin F 2009 Key signalling nodes in mammary gland development and cancer. Mitogenactivated protein kinase signalling in experimental models of breast cancer progression and in mammary gland development. Breast Cancer Research 11 209. (https://doi.org/10.1186/bcr2361)

Wildrick DM \& Boman BM 1988 Chromosome 5 allele loss at the glucocorticoid receptor locus in human colorectal carcinomas. Biochemical and Biophysical Research Communications 150 591-598. (https://doi.org/10.1016/0006-291x(88)90434-2)

Wintermantel TM, Bock D, Fleig V, Greiner EF \& Schütz G 2005 The epithelial glucocorticoid receptor is required for the normal timing of cell proliferation during mammary lobuloalveolar development but is dispensable for milk production. Molecular Endocrinology 19 340-349. (https://doi.org/10.1210/me.2004-0068)

Wu W, Chaudhuri S, Brickley DR, Pang D, Karrison T \& Conzen SD 2004 Microarray analysis reveals glucocorticoid-regulated survival genes that are associated with inhibition of apoptosis in breast epithelial cells. Cancer Research 64 1757-1764. (https://doi. org/10.1158/0008-5472.can-03-2546)

Xavier AM, Anunciato AKO, Rosenstock TR \& Glezer I 2016 Gene expression control by glucocorticoid receptors during innate immune responses. Frontiers in Endocrinology 7 31. (https://doi. org/10.3389/fendo.2016.00031)

Xu L, Glass CK \& Rosenfeld MG 1999 Coactivator and corepressor complexes in nuclear receptor function. Current Opinion in Genetics and Development 9 140-147 (https://doi.org/10.1016/S0959437X(99)80021-5)

Yang F, Ma Q, Liu Z, Li W, Tan Y, Jin C, Ma W, Hu Y, Shen J, Ohgi KA et al. 2017 Glucocorticoid receptor: MegaTrans switching mediates the repression of an ER $\alpha$-regulated transcriptional program. Molecular Cell 66 321-331.e6. (https://doi.org/10.1016/j.molcel.2017.03.019)

Yang H, Xia L, Chen J, Zhang S, Martin V, Li Q, Lin S, Chen J, Calmette J, Lu M et al. 2019 Stress-glucocorticoid-TSC22D3 axis compromises therapy-induced antitumor immunity. Nature Medicine 25 1428-1441. (https://doi.org/10.1038/s41591-019-0566-4)

Yano A, Fujii Y, Iwai A, Kageyama Y \& Kihara K 2006 Glucocorticoids suppress tumor angiogenesis and in vivo growth of prostate cancer cells. Clinical Cancer Research 12 3003-3009 (https://doi. org/10.1158/1078-0432.CCR-05-2085).

Yao Y, Yao QY, Xue JS, Tian XY, An QM, Cui LX, Xu C, Su H, Yang L, Feng YY et al. 2020 Dexamethasone inhibits pancreatic tumor growth in preclinical models: involvement of activating glucocorticoid receptor. Toxicology and Applied Pharmacology $\mathbf{4 0 1}$ 115118 (https://doi.org/10.1016/j.taap.2020.115118).

Yemelyanov A, Czwornog J, Chebotaev D, Karseladze A, Kulevitch E, Yang X \& Budunova I 2007 Tumor suppressor activity of glucocorticoid receptor in the prostate. Oncogene 26 1885-1896 (https://doi.org/10.1038/sj.onc.1209991).

Zhao XY, Malloy PJ, Krishnan AV, Swami S, Navone NM, Peehl DM \& Feldman D 2000 Glucocorticoids can promote androgenindependent growth of prostate cancer cells through a mutated androgen receptor. Nature Medicine 6 703-706 (https://doi. org/10.1038/76287).

Zheng Y, Izumi K, Li Y, Ishiguro H \& Miyamoto H 2012 Contrary regulation of bladder cancer cell proliferation and invasion by dexamethasone-mediated glucocorticoid receptor signals. Molecular Cancer Therapeutics 11 2621-2632 (https://doi.org/10.1158/15357163.MCT-12-0621).

Received in final form 12 March 2021

Accepted 14 April 2021

Accepted Manuscript published online 14 April 2021 https://erc.bioscientifica.com

https://doi.org/10.1530/ERC-20-0489 (c) 2021 Society for Endocrinology Published by Bioscientifica Ltd. Printed in Great Britain 